Article

\title{
The Effect of the Internal Side of Social Responsibility on Firm Competitive Success in the Business Services Industry
}

\author{
M. Isabel Sánchez-Hernández ${ }^{1}$, Dolores Gallardo-Vázquez ${ }^{2}$, Agnieszka Barcik ${ }^{3}$ \\ and Piotr Dziwiński ${ }^{4, *}$ \\ 1 Business Administration and Sociology Department, School of Economics, University of Extremadura \\ Ave. Elvas s/n, Badajoz 06006, Spain; isanchez@unex.es \\ 2 Financial Economics and Accountancy Department, School of Economics, University of Extremadura, \\ Ave. Elvas s/n, Badajoz 06006, Spain; dgallard@unex.es \\ 3 Department of Management and Transport, University of Bielsko-Biała, Willowa 2, \\ Bielsko-Biala 43-309, Poland; abarcik@ath.bielsko.pl \\ 4 Department of Law and Administration, The University of Dabrowa Górnicza, Cieplaka 1c, \\ Dąbrowa Górnicza 43-300, Poland \\ * Correspondence: pdziwinski@wsb.edu.pl; Tel.: +48-606-113-729
}

Academic Editor: Adam Jabłoński

Received: 27 December 2015; Accepted: 14 February 2016; Published: 18 February 2016

\begin{abstract}
This work focuses on the internal side of social responsibility of organizations in a regional context. Through a survey of 590 managers in classical business services (human-capital intensive) and representative of the productive economy of the Region of Extremadura (Spain), an empirical analysis is conducted. First, a factor analysis is conducted to explore the main dimensions of the internal face of Social Responsibility and second, a structural equations model is developed to look for a relationship with business competitiveness. Business performance and innovation are also considered in the model. The main contribution of the article is the establishment of a set of indicators that will help to build an ongoing and meaningful dialogue with employees improving their quality of life at work that will also serve as important guidance for the increasing of the firm's competitiveness through responsible human resources practices. Some suggestions for a research agenda emerge from this first attempt to approach the internal side of responsibility in business.
\end{abstract}

Keywords: human recources management (HRM); internal social responsibility (ISR); service sector; social responsibility (SR)

\section{Introduction}

The rise of service economy has been the predominant pattern over the last few years [1-3]. We know a great deal about the organization and management of Social Responsibility (SR) and the link with Human Resources Management (HRM), but comparatively little about how applicable this is to the service sector. In this work, we identify the components of the internal side of Social Responsibility in the services industry.

Freeman [4] gave a broad definition of stakeholders as any group or individual who can affect or is affected by the achievement of the organization's objectives. This author also highlights how stakeholders are simply constituents within and outside the organization, who have a stake in an organization's functioning and outcomes. The well-known Stakeholder Theory offers an instrumental value in providing a framework for guiding the actions of organizational members to ensure that the relationships that contribute to their financial viability are managed responsibly $[5,6]$. Some authors 
refer to the moral claim on the actions of the firms to define the stakeholders [7] such as consumers, employees, competitors, suppliers, government, as well as other actors in society. It is evident that the firm responds to multiple stakeholders for different reasons and in various ways [8,9].

According to the Stakeholder Theory, it is generally recognized that Social Responsibility (SR) has two dimensions: the external dimension and the internal one. On the one hand, the external dimension of SR is reflected in a large relationship of organizations with their communities. Companies interact with their external stakeholders when they provide business operations by guaranteeing economic activity, tax revenues, investing in the local economic system, concluding contracts with the local distributors, respecting human rights, and encouraging protection activities on environment by considering environmental concerns in business operations. On the other hand, the understudied internal side of SR has the emphasis on employees. Mason and Simmons [10] say that employees expect SR values similar to other stakeholders, arguing that employees seek functional, economic, psychological, and ethical benefits from their employing organizations. In this sense, if employers provide challenging, stimulating and fulfilling work, some functional benefits will be obtained and it will also be perceived as indicative of a socially responsible employer and a main driver of Internal Social Responsibility (ISR) practices [11,12].

In general terms, SR has been considered to be "an organization's obligation to maximize its positive impact on stakeholders and to minimize its negative impact" [13]. However, the heterogeneity of definitions has been highlighted by Matten and Moon [14], (p.405) when they said "SR is an umbrella term overlapping with some, and being synonymous with other, conceptions of business-society relation". According to the renewed definition by the European Commission, SR is the responsibility of enterprises for their impacts on society with reference to collaborate with stakeholders "to integrate social, environmental and ethical concerns, respect for human rights and consumer concerns into their business operations and their core strategy" [15] (p.7). Taking into account that classical organizational boundaries have become obsolete because "what once was 'outside' the organization is now 'inside' and vice versa" [16] (p.449) we found in this fact a fundamental reason for the emergence of the internal face of SR. Nowadays, the external side of SR and the internal one are more related than ever showing higher interconnectivity as have been shown by Sánchez-Hernández and Grayson [17]. According to this work, companies should discover the social and environmental potential of employees in order to integrate their interests and skills into the overall SR efforts. This will be the way to internalize a Social Responsible Strategy within the organization creating dynamic capabilities likely to lead to competitive advantages. The interaction of Strategy and HRM issues [18] explains how employees are important to a firm's success. According to the Resource-Based Theory (RBT) of the firm, human capital is a key factor explaining performance differences across firms [19]. In this respect, Crook [20] has pointed out the importance of "specific" employees, referring to the best and brightest human capital available in the labor market, to achieve high performance. Shoemaker [16] argued that treating HRM and SR separately is an outdated approach because organizations develop towards open systems where cooperative action is based on the willingness of employees to bring in and expand their talents as part of communities of work.

Despite the huge academic literature devoted to SR, literature about ISR is surprisingly scarce and empirical studies are inexistent as far as we know. However, the need for real improvement in organizational capability for doing well, and also for doing well in respect to stakeholders, as a basis for competitive strategy and competitive advantage, has received widespread attention in the academic and professional management literature [21]. In addition, competitive advantage is increasingly achieved through the mobilization of the accumulated know-how of individual employees to create value through processes that are not easily imitable [22]. Consequently, ISR has to be analyzed for one important reason: because employees are stakeholders able to create social value for the company mediating between the company and the consumers.

Worried about the under-studied internal side of SR, this work focuses upon regional businesses in Extremadura (Autonomous Region in the southwest of Spain) interacting with the local community 
by investing in the regional economic system, contracting with the local distributors, taking into account environmental concerns (external side of SR) and also recruiting employees, guaranteeing jobs, wages, training, and employees quality of life (the internal one).

The paper exposes what could be considered socially responsible management of human resources, called sustainable HRM — what actions related to human capital any organization could perform to state that employees' management is sustainable. In previous work, the authors have developed and empirically validated an SR scale in the regional context of study [23]. Now, we address internal practices considered sustainable in academic management literature by isolating the internal aspects of the general scale mentioned. For the definition of indicators that reflect these actions, we have covered several areas. All of them include some determinants of pleasant working conditions, and are oriented to the pursuit of social welfare [24-29].

There are many different areas that could be addressed. Thus, we start to refer to the actions devoted to support the employment of people at risk of social exclusion $[30,31]$ and, at the same time, the fact that the company values the contribution of disabled people to the business world [32-34]. Moreover, the interest in the employee's quality of life [29,35], the importance of payments of wages above the industry average and the existence of pension plans [36,37], or the fact that employee compensation will be related to their skills and results [38,39], are aspects that determine a responsible management into the organization. We can add the standards of health and safety beyond the legal minimum (because every company has to fulfill the law) [40], the commitment with the job creation [41] and the training and development programs for employees [32,42]. In addition, it is important to consider the conciliation of professional and personal lives $[43,44]$ and the equal opportunities for all employees [32,42,45-47]. In the line of social commitment, the participation of the organization in social projects $[48,49]$ and the organization of volunteer activities in collaboration with NGOs $[49,50]$, define new responsible actions in management.

Moreover, to be responsible, the organization must have dynamic mechanisms of dialogue with employees. In this respect, Preuss and others [51] conclude after some case study analyses that dialogue with employee representatives and trade unions could play an active role in SR and, in some cases, even a pivotal one. While the company is doing SR actions, it must raise awareness and inform employees on SR and the actions committed. Finally, the fact that the organization was an active member of any association that promotes the implementation of SR, as could be the case of the United Nations Global Compact for instance, is considered very important [52].

After this theoretical introduction, employees could be considered the center of any responsible business. European firms pursue SR for concerns of stakeholders such as government, regulatory bodies, customers or pressure groups. This is the external SR orientation. However, the aim of this paper is to study the ISR of organizations. In this sense, we say that SR behavior and values should also include internal aspects of management related to intra-organizational elements, organizational capabilities and HRM. As follows, through a survey of managers, we first carry on a factor analysis to explore the main dimensions of the ISR. Once the multidimensionality of this new construct is empirically determined, interpreted, and understood, the empirical analysis continues by looking for a relationship between ISR and business competitiveness. The work finishes with conclusions, limitations of the study, and lines of research for the near future.

\section{Method}

\subsection{Sample and Procedure}

The information for this investigation was collected from business services managers in the Autonomous Community of Extremadura, in southwestern Spain. The broad argument to choose services in this work is that the match between HRM and SR strategy should be greater in services than in manufacturing, highlighting the internal side of SR. According to Legge [53], services are competing in the knowledge-based economy. Services are used to characterize high skilled people and high cost 
industry. In this context, it is likely to adopt HRM policies very well linked to SR strategy that treat employees as an asset that enables the company to create added-value.

To justify the selected region, we have to say that, since 2010, a special plan for the promotion of SR exists in the Region. The main pillars for building a responsible culture in the region are: The Law of SR in Extremadura (15/2010 of 9 December) and the Decree (110/2013 of 2 July) for the establishment of the Autonomous Council for the promotion of Social Responsibility of Extremadura, the Office of Corporate Social Responsibility, and the Procedure for qualification and registration of socially responsible companies. At this point, it is important to highlight that the special plan for the promotion of SR in the Region is enhancing both the external and the internal side of SR. Table 1 presents the study's technical data sheet.

Table 1. Technical data sheet.

\begin{tabular}{ll}
\hline Data Sheet & \\
\hline Geographical Scope & Region of Extremadura (Spain) \\
Universe & SMEs (Small and medium-sized enterprises) Business Services-Source: \\
& Spain's Central Enterprise Directory 2009 \\
Method of information collection & Phone contact \\
Emitted calls & 14,580 \\
Population & 5332 contacted firms \\
Final sample & $590 \mathrm{SMEs}$ \\
Index of participation & $11.07 \%$ \\
Measurement error & $3.3 \%$ \\
Trust level & $95 \% \mathrm{z}=1.96 \mathrm{p}=\mathrm{q}=0.5$ \\
Sampling method & Simple random \\
Average duration of the interview & $14: 35$ (minutes:seconds) \\
\hline & \multicolumn{1}{c}{ Source: Own work. }
\end{tabular}

The representative sample of regional business services comprised 590 SMEs (Small and medium-sized enterprises) with their corresponding predetermined substitute firms to control the non-response index. The objective universe was drawn from Spain's Central Enterprise Directory (SCED). Before beginning the study, we calibrated the representativeness of the sample of firms that were to participate in the survey. To this end, weighting coefficients were established according to the defined strata of the firms in the sample. Possible biases relative to the characteristics of the total population of the Directory were checked for using statistical tests, comparing the structure of the sample with the total population of the SCED. The results justified the validity of the sample for the purposes of the study. A pilot test was also carried out in order to check that the survey would be appropriately interpreted by the respondent. The administration of one ad hoc questionnaire was by telephone interviews with business services managers. They were carried out using the Computer Aided Telephone Interviewing (CATI) system. The participation index was $11.07 \%$, corresponding to the percentage of firms in which a valid interlocutor agreed to participate in the study. A total of 590 completed surveys were collected, which resulted in a response rate of $11.07 \%$.

\subsection{The Measurement Instrument}

An ad hoc questionnaire was provided to inquire into the manager's perceptions with responses on a 10-point Likert scale. These responses went from " 0 : totally in disagreement" to "10: totally in agreement" for the ISR items, and from "0: far below the competition" to "10: far above the competition" for the items corresponding to the rest of the constructs. With this instrument, we analyze the ISR as a first attempt to standardize it aligned with the "Guidance on Social Responsibility" published for the International Organization for Standardization (ISO 26000) in 2010. The aim is to assist companies to expand their responsible behavior from external actions to internal actions looking for synergies and better performance. Thus, and according to previous work [23,32,54], the selected indicators reflecting ISR actions are shown in Table 2 (from INTR1 to INTR18) selectively supported by Turker [42], Agudo-Valiente et al. [45], Lu et al. [47] and Pérez et al. [46]. All indicators are considered 
internal activities related to ISR rather than external activities because, in these actions, we can observe how employees mediate the relationship between the company and the society.

Table 2. Selected indicators about the internal dimension of social responsibility (SR).

\begin{tabular}{|c|c|}
\hline Indicators & \\
\hline INTR1 & We support the employment of people at risk of social exclusion \\
\hline INTR2 & We value the contribution of disabled people to the business world \\
\hline INTR3 & We are aware of the employees' quality of life \\
\hline INTR4 & We pay wages above the industry average \\
\hline INTR5 & Employees compensation is related to their skills and their results \\
\hline INTR6 & We have standards of health and safety beyond the legal minimum \\
\hline INTR7 & We are committed to job creation (fellowships, creation of job opportunities, ... ) \\
\hline INTR8 & We foster our employees' training and development \\
\hline INTR9 & $\begin{array}{l}\text { We have human resource policies aimed at facilitating the conciliation of } \\
\text { employees' professional and personal lives }\end{array}$ \\
\hline INTR10 & Employees' initiatives are taken seriously into account in management decisions \\
\hline INTR11 & Equal opportunities exist for all employees \\
\hline INTR12 & We participate in social projects to the community \\
\hline INTR13 & $\begin{array}{l}\text { We encourage employees to participate in volunteer activities or in collaboration } \\
\text { with NGOs }\end{array}$ \\
\hline INTR14 & We have dynamic mechanisms of dialogue with employees \\
\hline INTR15 & We understand the importance of pension plans for employees \\
\hline INTR16 & $\begin{array}{l}\text { We put into practice specific actions to raise awareness, to educate, and to inform } \\
\text { employees on the principles and actions related to SR }\end{array}$ \\
\hline INTR17 & The values related to SR are present in the vision and strategy of the firm \\
\hline INTR18 & $\begin{array}{l}\text { We are active members of organizations, businesses, or professional association } \\
\text { or discussion groups that promote the implementation of SR }\end{array}$ \\
\hline
\end{tabular}

\subsection{Factor Analysis}

We observe that the selected indicators from the formulated domain of the internal side of SR offered in Table 2 are measures or variables related to ISR. However, we wonder whether they could be correlated with each other. In this case, it means that scores on each variable share information contained in the others [55]. In general, factor analysis is a collection of methods to explain the correlations among variables in terms of more fundamental elements called factors. Specifically, and according to Jolliffe [56], the central idea of a principal component analysis is to reduce the dimensionality of a data set in which there is a large number of interrelated variables, as is the case of the first approximation to ISR shown in Table 2, while retaining as much as possible of the variation present in the data set. This reduction is achieved by transforming the factors or principal components to a new set of variables, which are uncorrelated, and which are ordered so that the first few retain most of the variation present in all of the original variables. In addition, and considering that in the factor analysis literature attention has been given to the issue of sample size, it is important to remark that our sample $(N=590)$ is good enough. Taking into account the recommendations given by Mundfrom et al. [57] even under the worst imaginable conditions of low communities and a larger number of weakly determined factors, the very large required sample is over 500 .

In this research, a factor analysis is used as a method for grouping the proposed variables related to ISR according to a similar correlation pattern in order to discover the main factors for this construct. An exploratory principal components factor analysis has allowed us to check the factorial composition and validity. Thus, the initial 18-item instrument is performed to determine the structure of ISR. In our 
analysis, the value of the Kaiser-Meyer-Olkin measure of sampling adequacy $(\mathrm{KMO}=0.873)$ and the Bartlett sphericity test showed the existence of good correlations between the variables, so that we could continue with the factorial analysis. The principal components factor analysis with varimax rotation has produced five factors (Table 3).

We can observe how the eigenvalues and explained variance decline following the extraction of the first factor. The factors extracted explained $61 \%$ of the total variance. To validate the exploratory factor analysis, we took two random sub-samples. The validity of the factor analysis was confirmed since the communities of the sub-samples were found to be similar in value to those of the initial sample, the total explained variance was also similar, and the factor loadings after varimax rotation were also close to the initial sample. While the values of Cronbach's alpha is always lie between 0 and 1, the values calculated are all well in excess of the generally accepted rule-of-thumb lower limit of 0.60 to be acceptable [58]. Cronbach's alpha are good for the first three factors $\left(\alpha_{1}=0.813\right.$; $\left.\alpha_{2}=0.735 ; \alpha_{3}=0.711\right)$ and acceptable for the others $\left(\alpha_{4}=0.64 ; \alpha_{5}=0.67\right)$. This result is good enough because Cronbach's alpha has a positive relationship with the number of items in the scale and the questionnaire contained only 18 items. The magnitude of the alpha values obtained is an evidence for the internal consistency of the items forming the scales.

Table 3. Factor analysis.

\begin{tabular}{cccccc}
\hline Items & Factor 1 & Factor 2 & Factor 3 & Factor 4 & Factor 5 \\
\hline INTR10 & 0.754 & 0.106 & 0.137 & 0.105 & 0.122 \\
INTR14 & 0.747 & -0.010 & 0.248 & 0.081 & 0.171 \\
INTR11 & 0.737 & 0.031 & 0.145 & 0.206 & 0.103 \\
INTR9 & 0.659 & 0.153 & 0.100 & 0.136 & -0.014 \\
INTR8 & 0.656 & 0.276 & 0.031 & 0.278 & 0.074 \\
INTR7 & 0.433 & 0.315 & 0.014 & 0.244 & 0.113 \\
INTR18 & 0.059 & 0.785 & 0.126 & 0.045 & 0.049 \\
INTR17 & 0.179 & 0.729 & 0.262 & 0.005 & 0.163 \\
INTR16 & 0.160 & 0.708 & 0.230 & 0.176 & 0.003 \\
INTR13 & 0.115 & 0.144 & 0835 & 0.086 & 0.015 \\
INTR12 & 0.107 & 0.199 & 0.775 & 0.111 & 0.101 \\
INTR15 & 0.266 & 0.231 & 0.599 & 0.052 & -0.008 \\
INTR4 & 0.128 & 0.048 & 0.104 & 0.798 & 0.087 \\
INTR5 & 0.288 & -0.031 & 0.136 & 0.708 & 0.085 \\
INTR6 & 0.225 & 0.263 & 0.016 & 0.622 & 0.032 \\
INTR1 & 0.068 & 0.122 & 0.093 & 0.018 & 0.836 \\
INTR2 & 0.158 & 0.044 & -0.010 & 0.103 & 0.835 \\
INTR3 & 0.461 & 0.052 & 0.042 & 0.362 & 0.483 \\
\%ccumulated \% & 31.133 & 10.315 & 7.640 & 6.228 & 5.687 \\
\% of standard deviation & 31.133 & 41.448 & 49.088 & 55.316 & 61.003 \\
\hline
\end{tabular}

Notes: Determinant of the correlation matrix $=0.003$; Kaiser-Meyer-Olkin Index $=0.873$; Barlett Test $($ Chi-squared; sf) $=4335$ (153); Signification level $=0.000$. Source: Own work.

Another aspect of construct validity is the ability of factors to reflect the theoretical dimensions or those argued by academic literature accurately. The individual factors contributing to the ISR model and their theoretical explanation are the following:

- $\quad$ Factor one-Responsible HR (RHR) (31.1\% of explained variance): This factor can be described and interpreted as representing the responsiveness of HRM policies in respect to employees' needs and wants. This first factor is aligned with previous work in Internal Marketing [17,59] where employees are considered clients, internal clients, and a very important stakeholder to attend. Job creation, training, conciliation and equal opportunities and dynamic mechanisms of employees' participation in management decisions fostering dialogue form part of this composite factor.

- $\quad$ Factor two-Responsible Organizational Culture (ROC) (10.3\% of explained variance): Internalization of SR principles and values into the vision and strategy of the business, relationship with associations promoting SR, and the effort to communicate SR aspects to employees internally form the essential elements of a culture of responsibility and form this second factor in the analysis. 
In this respect, some authors have highlighted the importance of the culture of responsibility as the first step to become a responsible business $[17,60]$.

- Factor three-HR and Social Issues (HRSI) (7.6\% of explained variance): This factor can be best described as representing the link between internal HRM practices and the external side of SR in their relationship with the community in any effort for attending social issues. Being aware of problems in society including pension plans for retirement and fostering corporate volunteering are included in this factor and theoretically defended before in the same context [49] and previously in others [61,62].

- Factor four-Responsible Compensation ( $R C$ ) (6.2\% of explained variance): Aligned to previous studies [63,64], going beyond the legal minimum and beyond the average in the sector in human resources tools such as wages, health and safety and linking employees' compensation to their performance, form the essential elements of this factor.

- Factor five-Employees Quality of Life (EQL) (5.6\% of explained variance): The essential element of this final factor forming ISR, also previously analyzed [29], is the aim to improve employees' quality of life including the disabled and people in risk of social exclusion.

These five factors were perceived as ISR dimensions for the purposes of our study, and their compatibility with the following step in this research is indicative of the validity of the study. In addition, the requirement of discriminant validity to demonstrate that any indicator should correlate more highly with another construct than with the construct it intends to measure [65] is also satisfactory in all factors in the analysis. Once the five dimensions have been found and described, the path analysis to test the relationship between ISR and competitive success is carried out in the following session.

\subsection{Path Analysis}

Structural equations modeling (SEM) has been used, considering it is very suitable for our research interests, because the construct under study, ISR, is relatively new and the theoretical model and their measures are not well formed [66]. According to literature review, when companies are involved in SR activities, the internal dimension determines relations with their internal stakeholders, especially their employees, and higher competitive success could be expected. Business performance and innovation have also been considered in the developed structural model. The relationship between performance and competitive success has been noted in business strategy fieldwork by Porter $[67,68])$ and other authors [69,70], and previous work has demonstrated the mediation role of innovation between SR and competitive success [32]. Innovation that is intrinsically about identifying and using opportunities to create new products, services, or work practices [71] is also identified in the model as a mediator variable when considering ISR because it is theoretically and widely accepted that improvements to HRM have a positive impact on innovation [72,73]. According to Cano and Cano [74], certain HR practices such as goal recognition or reward for achievement, have a positive effect on innovation performance in the company. In fact, these HR improvements promote the ability to innovate because they first improve the ability to deal with complexity [75]. In addition, academic literature on HRM has demonstrated how better HR practices are also linked to firm performance [76]. Finally, the link of these previous variables to competitive success is the soul of the Resource-Based Theory of the firm [5,6] previously exposed. The focus of management on sustainable HRM is the key to enhance employee commitment and satisfaction, which, in turn, increases the service innovation and performance, and will ultimately generate better overall competitive success [77]. The model shown in Figure 1 includes four related latent variables that make up the proposed relationships defined in the following hypotheses.

Hypothesis 1-There is a direct and positive relationship between the ISR and business performance.

Hypothesis 2-There is a direct and positive relationship between business performance and competitive success.

Hypothesis 3-There is a direct and positive relationship between the ISR and innovation.

Hypothesis 4-There is a direct and positive relationship between innovation and competitive success. 


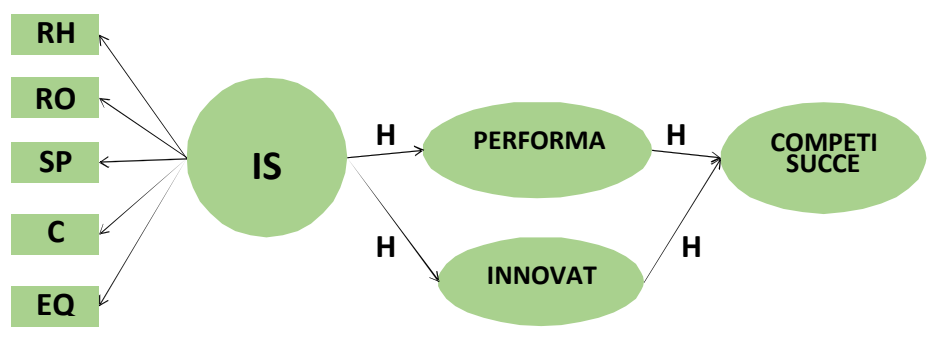

Figure 1. The structural model. Source: own work.

To measure ISR, we have considered the five dimensions found in the previous factor analysis (with the sort names RHR, ROC, HRSI, RC and EQL). Consequently, ISR has been defined as a second order construct. Indicators for each dependent variable are shown in Table 4.

Table 4. Original Indicators for performance, innovation and competitive success.

\begin{tabular}{|c|c|}
\hline & Indicators for Performance (PER), Innovation (INV) and Competitive Success (COM) \\
\hline PER1 & Level of before-tax profits \\
\hline PER2 & Level of profitability \\
\hline PER3 & Increase in sales \\
\hline PER4 & Profit margin \\
\hline PER5 & Market share for our products and/or services \\
\hline PER6 & Level of customer satisfaction and loyalty \\
\hline PER7 & Satisfaction and retention of the best employees \\
\hline PER8 & Market positioning, image, and reputation \\
\hline INV1 & We try to carry out R\&D projects \\
\hline INV2 & We have put new products or services on the market \\
\hline INV3 & We have introduced new practices to foster entry into new national markets \\
\hline INV4 & We have introduced new practices to foster entry into new international markets \\
\hline INV5 & $\begin{array}{l}\text { We are aware of the importance of working as a network, and we have created new alliances } \\
\text { or associations }\end{array}$ \\
\hline INV6 & We have put into place improvements in our production and/or distribution process or techniques \\
\hline INV7 & We have intensified our information and communication technologies \\
\hline INV8 & We have increased our presence on the Internet \\
\hline INV9 & We have initiated changes in the marketing area (design, packaging, prices, ... ) \\
\hline INV10 & Our firm has introduced new methods with a view to satisfying the norms of certification \\
\hline INV11 & $\begin{array}{l}\text { We have implemented internal or external employee training in order to improve knowledge and } \\
\text { creativity within the firm }\end{array}$ \\
\hline INV12 & $\begin{array}{l}\text { We have implemented new managerial practices related to the organization of work and the } \\
\text { corporate structure }\end{array}$ \\
\hline INV13 & $\begin{array}{l}\text { We have introduced standards of production or customer management that take social and } \\
\text { environmental aspects into account }\end{array}$ \\
\hline COM1 & Quality in our human resource management \\
\hline COM2 & The levels of training and empowerment of our personnel \\
\hline COM3 & The leadership capabilities of our managers \\
\hline COM4 & Our capabilities in the field of marketing \\
\hline COM5 & Quality of our products and services \\
\hline COM6 & The levels of organizational and administrative management quality \\
\hline COM7 & Technological resources and information systems \\
\hline COM8 & Transparency of our financial management \\
\hline COM9 & The cohesion of our corporate values and culture \\
\hline COM10 & Market knowledge, know-how, and accumulated experience \\
\hline
\end{tabular}


To measure performance, innovation and competitive success, we have considered scales previously used by Gallardo-Vázquez and Sánchez-Hernández [32]. Performance is considered a reflective construct with eight indicators (from PER1 to PER8) as well as innovation with thirteen indicators (from INV1 to INV13) and competitive success with ten indicators (from COM1 to COM10). At this point, it is important to distinguish performance from competitive success in the model. Performance considers firm results going beyond short-term financial performance and pursuing sustainable development. Instead, competitive success considers aspects of competition. Firms have competitive success when they are able to attain favorable positions in the market and obtain superior results, while avoiding the need to have recourse to an extremely poor retribution of the factors of production. Consequently, competitive success implies getting better positions than your competitors because of "something more" than performance.

For the measurement of performance, this construct was taken to be multi-dimensional in accordance with the literature and basing the dimensions considered on a combination of the contribution of Wiklund and Shepherd [78] with that of Pelham and Wilson [79] to include growth in market share and sales. In addition, we consider a very broad conception of innovation. The construct is conceived as the adoption of new idea or practice capable of leading to new products or services [80] to enter new markets [81] or to the generation of new organizational or administrative processes [82].

With respect to the last dependent variable in the model, a firm was taken to have competitive success when it is able to attain a favorable position in the market and obtain superior results, while avoiding the need to have recourse to an extremely poor retribution of the factors of production. To measure competitive success, we used indicators previously considered in academic literature [83,84].

Once the model and related constructs have been described, the first statistical step was to analyze whether the theoretical concepts where properly measured by the observed indicators. This analysis was carried out for the two attributes validity (measuring what one really wanted to measure) and reliability (whether the process is stable and consistent). To this end, we calculate the individual item reliability, the internal consistency or reliability of the scales, the average variances extracted (AVE), and the discriminant validity. Results are shown in Table 5.

Table 5. Results from the measurement model.

\begin{tabular}{cccccc}
\hline Constructs & $\begin{array}{c}\text { Reliable } \\
\text { Indicators }\end{array}$ & Loadings $(\lambda)$ & AVE & $\begin{array}{c}\text { Crombach's } \\
\text { Alpha }\end{array}$ & $\begin{array}{c}\text { Composite } \\
\text { Reliability }\end{array}$ \\
\hline \multirow{5}{*}{ ISR } & RHR & 0.671 & & & \\
& ROC & 0.728 & 0.5167 & 0.6943 & 0.8097 \\
& RC & 0.671 & & & \\
EQrformance & EQL & 0.675 & & & \\
& D6 & 0.892 & & 0.9004 \\
& D7 & 0.906 & 0.7514 & & \\
& D8 & 0.798 & & & \\
Innovation & INV5 & 0.717 & & & \\
& INV6 & 0.678 & & & \\
& INV7 & 0.768 & & & \\
& INV8 & 0.698 & & & \\
& INV9 & 0.721 & 0.5336 & & \\
& INV11 & 0.772 & & & \\
& INV12 & 0.785 & & & \\
& INV13 & 0.695 & & & \\
\hline
\end{tabular}


Table 5. Cont.

\begin{tabular}{cccccc}
\hline Constructs & $\begin{array}{c}\text { Reliable } \\
\text { Indicators }\end{array}$ & Loadings $(\lambda)$ & AVE & $\begin{array}{c}\text { Crombach's } \\
\text { Alpha }\end{array}$ & $\begin{array}{c}\text { Composite } \\
\text { Reliability }\end{array}$ \\
\hline & COM1 & 0.761 & & & \\
COMpetitive & COM2 & 0.784 & & & \\
Success & COM5 & 0.768 & 0.5768 & 0.8530 & 0.8909 \\
& COM6 & 0.800 & & \\
& COM8 & 0.7408 & & \\
\hline
\end{tabular}

The most remarkable result in this step is the confirmation of four of the five dimensions found in ISR. The dimension linking HRM and Social Issues, factor three, has been removed from the model, as we have kept only factor loadings greater than 0.67 on ISR construct, which implies more shared variance between ISR and its four items than error variance [85].

The second step of the analysis of the structural model consisted of the estimation of the assumed linear relationships among exogenous and endogenous latent constructs. The correlations among study variables are shown in Table 6. Correlations indicate that the managers' perceptions regarding the ISR of their company were positively related to competitive success, innovation and performance, providing preliminary support for hypotheses.

Table 6. Inter-correlations matrix.

\begin{tabular}{lcccc}
\hline \multicolumn{1}{c}{ Variable } & $\mathbf{1}$ & $\mathbf{2}$ & $\mathbf{3}$ & $\mathbf{4}$ \\
\hline 1. ISR & 1 & & & \\
2. Innovation & 0.505 & 1 & & \\
3. Performance & 0.242 & 0.161 & 1 & \\
4. Competitive Success & 0.394 & 0.312 & 0.575 & 1 \\
\hline \multicolumn{5}{c}{ Source: Own work. }
\end{tabular}

The hypotheses have been tested by examining the magnitude of the standardized parameters estimated between constructs with the corresponding $t$-values that indicate the level of significance. We employ the bootstrap routine [66], a non-parametric re-sampling technique that offers the $t$-statistic values. All hypotheses were verified as it is shown in Table 7.

Table 7. Hypotheses testing.

\begin{tabular}{ccccc}
\hline $\begin{array}{c}\text { HYPOTHESIS/Structural Relation } \\
\mathbf{A} \rightarrow \mathbf{B}\end{array}$ & $\begin{array}{c}\text { Original Path } \\
\text { Coefficients }(\boldsymbol{\beta})\end{array}$ & $\begin{array}{c}\text { Mean of Sub-Sample } \\
\text { Path Coefficients }\end{array}$ & Standard Error & $\boldsymbol{t}$-Value \\
\hline $\boldsymbol{H}_{\mathbf{1}}$ : ISR $\rightarrow$ Performance & 0.2425 & 0.2453 & 0.0729 & $3.32^{* * *}$ \\
$\boldsymbol{H}_{\mathbf{2}}$ : Performance $\rightarrow$ Competitive Success & 0.5394 & 0.5504 & 0.0530 & $10.17^{* * *}$ \\
$\boldsymbol{H}_{\mathbf{3}}:$ ISR $\rightarrow$ Innovation & 0.5054 & 0.5133 & 0.0550 & $9.16^{* * *}$ \\
$\boldsymbol{H}_{\mathbf{4}}$ : Innovation $\rightarrow$ Competitive Success & 0.2249 & 0.2242 & 0.0542 & $4.14^{* * *}$ \\
\hline & Source: Own work.
\end{tabular}

Finally, to measure the relevance of the dependent construct's prediction, PLS (Partial Least Squares) uses the $\mathrm{Q}^{2}$ index from Stone-Geisser as a criterion, which is calculated based on the redundancies that result from the product of communities $\left(\lambda^{2}\right)$ with the AVE indicator and is also cross-validated. According to Chin [86], the Stone-Geisser criterion $Q^{2}$ values have been obtained from running a blindfolding procedure and range above the threshold level of zero ( 0.48 for performance; 0.40 for innovation; 0.45 for competitive success), indicating that the exogenous constructs have predictive relevance for the endogenous construct under consideration. 


\section{Results and Discussion}

While acknowledging that the regional context of the study puts limits on the generalization of our findings, we nonetheless see a number of interesting conclusions. The main contribution of the article is the establishment of a set of indicators that define ISR as a result of a dynamic process that provides information about a firm's actions in responsible HRM. This article argues in favor of a stronger focus upon the management of ISR policies and practices in enterprises. Our results show the main factors determining the ISR structure as they have been perceived by a big sample of services business managers in the region under study. The obtained empirical evidence is a contribution to the SR research where there is a lack in studies devoted to the internal side. Therefore, this study contributes to the generation of knowledge on internal responsible behavior of companies. As demonstrated, ISR in service business, which is more influenced by human resources practices, is defined by five well-delimited dimensions such as: responsible human resources practices; organizational culture of responsibility; social projects promotion; significant compensation policies and employee quality of life. A point of interest that needs to be highlighted is the important role that HRM could play in the SR strategy of any business, an aspect that has been analyzed with the developed structural equation model.

It has been demonstrated empirically that ISR has an effect on increasing the firm's competitiveness. The conceptual model has been tested empirically confirming the four hypotheses $\mathrm{H}_{1}, \mathrm{H}_{2}, \mathrm{H}_{3}$ and $\mathrm{H}_{4}$. Consequently, the model has been validated where innovation and performance have the role of mediator variables between ISR and competitive success in accordance with previous work in general SR [23,32], where ISR was not isolated from the holistic construct of firm responsibility.

\section{Conclusions}

Although an abundance of research exists on the general topic of SR, little has been run toward identifying, or perhaps more importantly, measuring its internal aspects in business services. This investigation provides ample foundation for further research on this topic and contributes to a better appreciation and understanding of the role of responsible HRM practices.

To conclude, it should be noted that results from the analysis should be interpreted for SMEs, overcoming the limitations coming from the regional context of study and also from the selection of the sample limited to the service sector, and limited to a single Spanish Autonomous Community. Consequently, our results are not directly extrapolated to other environments that differed greatly in their defining variables. However, since the predominance of business services and the predominance of SMEs are characteristic for the whole Spanish territory, and even the whole European Union, we can accept the results satisfactorily. We believe that our study represents a substantial contribution to the knowledge of ISR, but, in the near future, qualitative and quantitative research should be done on the topic. Managers have to be aware that one of the most important stakeholders the company has is the employee. Employees have to be considered an internal client $[59,87]$ and, consequently, SR should start inside the company. In fact, we question whether there is sufficient focus upon investment in employees, which could be regarded as an important driver of external SR practice [88].

Some suggestions for a research agenda emerge from this attempt to approach the internal side of responsibility in business. First, new studies in the same direction but in other sectors and regions have to be addressed, and second, and related to SR and internal management, we suggest an analysis of the theoretical and hypothetical relationship between the internal and the external side of SR in order to determine the direct effect in external SR fostered by responsible HR policies internally. In line with other authors [59,89], we remark on the importance of internal marketing as a way to sell the responsible company culture internally to employees to somehow help external SR to develop at the same time that companies improve their competitive success. The more important the concept and practice of ISR becomes, the more likely the companies will improve their competitive advantage. It should be taken as an important opportunity for the responsible reinvention of management. 
In conclusion, ISR and HRM are interrelated concepts influencing the business competitive success, and their effectiveness depends on responsible practices inside the spheres of the company.

Acknowledgments: The authors are grateful to all the managers in business services who participated in the survey and contributed to the paper.

Author Contributions: M. Isabel Sánchez-Hernandez designed the research, analyzed the data and wrote the manuscript, Dolores Gallardo-Vázquez collected data and performed research, Agnieszka Barcik analyzed the data and revised the research and paper, and Piotr Dziwiński analyzed the data, revised the research and corrected the final version of manuscript.

Conflicts of Interest: The authors declare no conflict of interest.

\section{References}

1. Peneder, M.; Kaniovski, S.; Dachs, B. What follows tertiarisation? Structural change and the role of knowledge-based services. Serv. Ind. J. 2003, 23, 47-66. [CrossRef]

2. Ehret, M.; Wirtz, J. Division of labor between firms: Business services, non-ownership-value and the rise of the service economy. Serv. Sci. 2010, 2, 136-145. [CrossRef]

3. Buera, F.J.; Kaboski, J.P. Scale and the origins of structural change. J. Econ. Theory 2012, 147, 684-712. [CrossRef]

4. Freeman, R.E. Strategic Management: A Stakeholder Approach, 1st ed.; Harpercollins College Div., Pitman Series: Marshfield, MA, USA, 1994.

5. Donaldson, T.; Preston, L. The Stakeholder Theory of the Corporation: Concepts, Evidence, and Implications. Acad. Manag. Rev. 1995, 1, 65-91.

6. Freeman, R.E.; Harrison, J.E.; Wicks, A.C. Managing for Stakeholders: Survival, Reputation, and Success; Yale University Press: New Haven, CT, USA, 2007.

7. Kaler, J. Evaluating stakeholder theory. J. Bus. Eth. 2006, 69, 249-268. [CrossRef]

8. Berrone, P.; Surroca, J.; Tribo, J.A. Corporate ethical identity as a determinant of firm performance: A test of the mediating role of stakeholder satisfaction. J. Bus. Eth. 2007, 76, 35-53. [CrossRef]

9. Verbeke, A.; Tung, V. The Future of Stakeholder Management Theory: A Temporal Perspective. J. Bus. Eth. 2013, 112, 529-543. [CrossRef]

10. Mason, C.; Simmons, J. Embedding Corporate Social Responsibility in Corporate Governance: A Stakeholder Systems Approach. J. Bus. Eth. 2013, 119, 77-86. [CrossRef]

11. Mont, O.; Leire, C. Socially responsible purchasing in supply chains: Drivers and barriers in Sweden. Soc. Responsib. J. 2009, 5, 389-407. [CrossRef]

12. Barcik, A.; Dziwiński, P. Relations with employees in CSR strategies at Polish enterprises with regard to compliance mechanism. Responsib. Sustain. 2015, 3, 13-26.

13. Ferrell, O.C.; Fraedrich, J.; Ferrell, L. Business Ethics: Ethical Decision Making and Cases; Houghton Mifflin: Boston, MA, USA, 2008.

14. Matten, D.; Moon, M. "Implicit" and "explicit" CSR: A conceptual framework for a comparative understanding of Corporate Social Responsibility. Acad. Manag. Rev. 2008, 33, 404-424. [CrossRef]

15. Commission of the European Communities, COM. Communication from the Commission to the European Parliament, the Council, the European Economic and Social Committee and the Committee of the Regions. Available online: http://eur-lex.europa.eu/legal-content/EN/TXT/?uri=CELEX\%3A52011DC0681 (accessed on 17 February 2016).

16. Schoemaker, M.; Nijhof, A.; Jonker, J. Human value management. The influence of the contemporary developments of corporate social responsibility and social capital on HRM. Manag. Rev. 2006, 17, 448-465.

17. Sánchez-Hernández, M.I.; Grayson, D. Internal marketing for engaging employees on the corporate responsibility journey. Intang. Cap. 2012, 8, 275-307. [CrossRef]

18. Barney, J. Firm resources and sustained competitive advantage. J. Manag. 1991, 17, 99-120. [CrossRef]

19. Acedo, F.J.; Barroso, C.; Galán, J.L. The resource-based theory: Dissemination and main trends. Strateg. Manag. J. 2006, 27, 621-636. [CrossRef]

20. Crook, T.R.; Todd, S.Y.; Combs, J.G.; Woehr, D.J.; Ketchen, D.J., Jr. Does human capital matter? A meta-analysis of the relationship between human capital and firm performance. J. Appl. Psychol. 2011, 96, 443-456. [CrossRef] [PubMed] 
21. Porter, M.E.; Kramer, M.R. The link between competitive advantage and corporate social responsibility. Harv. Bus. Rev. 2006, 84, 78-92. [PubMed]

22. Varey, R.J. Internal marketing: A review and some interdisciplinary research challenges. Int. J. Serv. Ind. Manag. 1995, 6, 40-63. [CrossRef]

23. Gallardo-Vázquez, D.; Sánchez-Hernández, M.I. Measuring Corporate Social Responsibility for competitive success at a regional level. J. Clean. Prod. 2014, 72, 14-22. [CrossRef]

24. Carroll, A. A three-dimensional conceptual model of corporate performance. Acad. Manag. Rev. 1979, 4, 497-505.

25. Aupperle, K.; Carroll, A.B.; Hatfield, J. An empirical examination of the relationship between corporate social responsibility and profitability. Acad. Manag. J. 1985, 28, 446-463. [CrossRef]

26. Wood, D.J.; Jones, R.E. Stakeholder mismatching: A theoretical problem in empirical research on corporate social performance. Int. J. Organ. Anal. 1995, 3, 229-267. [CrossRef]

27. Quazi, A.M.; O'Brien, D. An empirical test of a cross-national model of corporate social responsibility. J. Bus. Eth. 2000, 25, 33-51. [CrossRef]

28. Maignan, I.; Ferrell, O.C. Measuring Corporate Citizenship in Two Countries: The Case of the United States and France. J. Bus. Eth. 2000, 23, 283-297. [CrossRef]

29. Sánchez-Hernández, M.I.; García-Míguelez, M.P. Improving Employees Quality of Life. In Best Practices in Marketing and Their Impact on Quality of Life; Alves, H., Vázquez, J.L., Eds.; Springer Dordrecht Heidelberg: New York, NY, USA; London, UK, 2013; pp. 241-254.

30. Zinn, J.O. Introduction: Risk, social inclusion and the life course. Soc. Policy Soc. 2013, 12, 253-264. [CrossRef]

31. Hayman, L.W.; McIntyre, R.B.; Abbey, A. The bad taste of social ostracism: The effects of exclusion on the eating behaviors of African-American women. Psychol. Health 2014, 3, 1-16. [CrossRef] [PubMed]

32. Gallardo-Vázquez, D.; Sánchez-Hernández, M.I. Corporate Social Responsibility in Extremadura; Fundación Obra Social La Caixa: Badajoz, Spain, 2012. (In Spanish)

33. Bruyére, S.; Filiberto, D. The green economy and job creation: Inclusion of people with disabilities in the USA. Int. J. Green Econ. 2013, 7, 257-275. [CrossRef]

34. Kulkarni, M.; Rodrigues, C. Engagerment with disability: Analysis of annual reports of Indian organizations. Int. J. Human Resour. Manag. 2014, 25, 1547-1566. [CrossRef]

35. Cullinane, S.J.; Bosak, J.; Flood, P.C.; Demerouti, E. Job design under lean manufacturing and the quality of working life: A job demands and resources perspective. Int. J. Human Resour. Manag. 2014, 25, 2996-3015. [CrossRef]

36. Amstrong, M. Amstrong's Handbook of Reward Management Practice. In Improving Performance through Reward, 4th ed.; Kogan Page: London, UK, 2012.

37. Esping-Andersen, G. The Three Worlds of Welfare Capitalism; John Wiley \& Sons: Chichester, UK, 2013.

38. Cohen, E. CSR for HR: A Necessary Partnership for Advancing Responsible Business Practices; Greenleaf Publishing Limited: Sheffield, UK, 2010.

39. Long, C.S.; Perumal, P. Examining the impact of human resource management practices on employees' turnover intention. Int. J. Bus. Soc. 2014, 15, 111-126.

40. Lozano, R.; Huisingh, D. Inter-linking issues and dimensions in sustainability reporting. J. Clean. Prod. 2011, 19, 99-107. [CrossRef]

41. Bischoff, C.; Wood, G. Micro and small enterprises and employment creation: A case study of manufacturing micro and small enterprises in South Africa. Dev. South. Afr. 2013, 30, 564-579. [CrossRef]

42. Turker, D. Measuring Corporate Social Responsibility: A Scale Development Study. J. Bus. Eth. 2009, 85, 411-427. [CrossRef]

43. Vázquez-Carrasco, R.; López-Pérez, M.E.; Centeno, E. A qualitative approach to the challengues for women in management: Are they really starting in the 21st century? Qual. Quant. 2012, 46, 1337-1357. [CrossRef]

44. Tato-Jiménez, J.L.; Bañegil-Palacios, T.M. Effects of formal and informal practices of reconciling work and life on the performance of Spanish listed companies. Res. J. Bus. Manag. 2015, 9, 391-403. [CrossRef]

45. Agudo-Valiente, J.M.; Garcés-Ayerbe, C.; Salvador-Figueras, M. Social responsibility practices and evaluation of corporate social performance. J. Cleaner Prod. 2012, 35, 25-38. [CrossRef]

46. Pérez, A.; Martínez, P. Rodríguez del Bosque, I. The development of a stakeholder-based scale for measuring corporate social responsibility in the banking industry. Serv. Bus. 2012, 7, 459-481. [CrossRef] 
47. Lu, R.X.A.; Lee, P.K.C.; Cheng, T.C. Socially responsible supplier development: Construct development and measurement validation. Int. J. Prod. Econ. 2012, 140, 160-167. [CrossRef]

48. Hillman, A.J.; Keim, G.D. Shareholder value, stakeholder management, and social issues: What's the bottom line? Strateg. Manag. J. 2001, 22, 125-139. [CrossRef]

49. Sanchez-Hernandez, M.I.; Gallardo-Vázquez, D. Approaching corporate volunteering in Spain. Corpor. Gov. 2013, 13, 397-411. [CrossRef]

50. Knutsen, W.L.; Chan, Y. The Phenomenon of Staff Volunteering: How Far Can You Stretch the Psychological Contract in a Nonprofit Organization? VOLUNTAS Int. J. Volunt. Nonprofit Organ. 2015, 26, 1-22. [CrossRef]

51. Preuss, L.; Haunschild, A.; Matten, D. The rise of CSR: Implications for HRM and employee representation. Int. J. Hum. Resour. Manag. 2009, 20, 953-973. [CrossRef]

52. Cetindamar, D. Corporate social responsibility practices and environmentally responsible behavior: The case of the United Nations Global Compact. J. Bus. Eth. 2007, 76, 163-176. [CrossRef]

53. Legge, K. Human Resource Management: Rhetorics and Realities. MacMillan Press: London, UK, 1995.

54. Gallardo-Vázquez, D.; Sánchez-Hernández, M.I. Structural analysis of the strategic orientation to environmental protection in SME's. BQR-Bus. Res. Q. 2014, 17, 115-128. [CrossRef]

55. Cudeck, R. Exploratory Factor Analysis. In Handbook of Applied Multivariate Statistics and Mathematical Modeling; Tinsley, H., Brown, S., Eds.; Academic Press: San Diego, CA, USA, 2000; pp. 265-296.

56. Jolliffe, I. Principal Component Analysis; John Wiley \& Sons: Chichester, UK, 2005.

57. Mundfrom, D.J.; Shaw, D.G.; Ke, T.L. Minimum sample size recommendations for conducting factor analyses. Int. J. Test. 2005, 5, 159-168. [CrossRef]

58. Nunnally, J.C.; Bernstein, I.H. Psychometric Theory, 3rd ed.; McGraw Hill: New York, NY, USA, 1994.

59. Sánchez-Hernández, M.I.; Miranda, F.J. Linking internal market orientation and new service performance. Eur. J. Innov. Manag. 2011, 14, 207-226. [CrossRef]

60. Pohl, M. Corporate Culture and CSR-How They Interrelate and Consequences for Successful Implementation. In The ICCA Handbook on Corporate Social Responsibility; Hennigfeld, J., Pohl, M., Tolhurst, N., Eds.; John Wiley \& Sons: Chichester, UK, 2006.

61. Muthuri, J.N.; Matten, D.; Moon, J. Employee volunteering and social capital: Contributions to corporate social responsibility. Br. J. Manag. 2009, 20, 75-89. [CrossRef]

62. Kim, H.R.; Lee, M.; Lee, H.T.; Kim, N.M. Corporate social responsibility and employee-company identification. J. Bus. Eth. 2010, 95, 557-569. [CrossRef]

63. Mahoney, L.S.; Thorne, L. Corporate social responsibility and long-term compensation: Evidence from Canada. J. Bus. Eth. 2005, 57, 241-253. [CrossRef]

64. Collier, J.; Esteban, R. Corporate social responsibility and employee commitment. Bus. Eth. A Eur. Rev. 2007, 16, 19-33. [CrossRef]

65. Barclay, D.; Higgins, C.; Thompson, R. The partial least squares (PLS) approach to causal modeling: Personal computer adoption and use as an illustration. Technol. Stud. 1995, 2, 285-309.

66. Chin, W. Issues and Opinion on Structural Equation Modelling. MIS Q. 1998, 2, vii-xv.

67. Porter, M.E. Competitive Strategy: Techniques for Analyzing Industries and Competitors; The Free Press: New York, NY, USA, 1980.

68. Porter, M.E. Towards a dynamic theory of strategy. Strateg. Manag. J. 1991, 12, 95-117. [CrossRef]

69. Spanos, Y.E.; Lioukas, S. An Examination into the Causal Logic of Rent Generation: Contrasting Porter's Competitive Strategy Framework and the Resource Based Perspective. Strateg. Manag. J. 2001, 22, 907-934. [CrossRef]

70. Wagner, M.; Schaltegger, S. Introduction: How Does Sustainability Performance Relate to Business Competitiveness? Greener Manag. Int. 2003, 44, 5-16. [CrossRef]

71. Van de Ven, A.H. Central problems in the management of innovation. Manag. Sci. 1986, 32, 590-660. [CrossRef]

72. Sánchez-Hernández, M.I.; Gallardo-Vazquez, D.; Dziwiński, P.; Barcik, A. Innovation through corporate social responsibility-Insights from Spain and Poland. In Handbook of Research on Internationalization of Entrepreneurial Innovation in the Global Economy; IGI Global: Hershey, PA, USA, 2015; pp. 313-328.

73. Subramaniam, M.; Youndt, M.A. The influence of intellectual capital on the types of innovative capabilities. Acad. Manag. J. 2005, 48, 450-463. [CrossRef] 
74. Cano, C.P.; Cano, P.Q. Human resources management and its impact on innovation performance in companies. Int. J. Technol. Manag. 2006, 35, 11-28. [CrossRef]

75. Lund Vinding, A. Absorptive capacity and innovative performance: A human capital approach. Econ. Innov. New Technol. 2006, 15, 507-517. [CrossRef]

76. Mavondo, F.T.; Chimhanzi, J.; Stewart, J. Learning orientation and market orientation: Relationship with innovation, human resource practices and performance. Eur. J. Mark. 2005, 39, 1235-1263. [CrossRef]

77. Little, M.M.; Dean, A.M. Links between service climate, employee commitment and employees' service quality capability. Manag. Serv. Qual. Int. J. 2006, 16, 460-476. [CrossRef]

78. Wiklund, J.; Shepperd, D. Knowledge-based resources, entrepreneurial orientation and the performance of small and medium-sized businesses. Strateg. Manag. J. 2003, 24, 1307-1314. [CrossRef]

79. Pelham, A.; Wilson, D. A longitudinal study of the impact of market structure, firm structure, strategy, and market orientation culture on dimensions of small-firm performance. Am. Mark. Assoc. 1996, 24, 27-43. [CrossRef]

80. Yalcinkaya, G.; Calantone, R.J.; Griffith, D.A. An examination of exploration and exploitation capabilities: Implications for product innovation and market performance. J. Int. Mark. 2007, 15, 63-93. [CrossRef]

81. Medrano-Sáez, N.; Olarte-Pascual, M.C. Marketing Innovation as an Opportunity in a Situation of Uncertainty: The Spanish Case, 327-341. In Soft Computing in Management and Business Economics; Springer: Berlin Heidelberg, Germany, 2012.

82. Carmona-Lavado, A.; Cuevas-Rodríguez, G.; Cabello-Medina, C. Social and organizational capital: Building the context for innovation. Ind. Mark. Manag. 2010, 39, 681-690. [CrossRef]

83. Hughes, M.; Ireland, R.D.; Morgan, R.E. Stimulating dynamic value: Social capital and business incubation as a pathway to competitive success. Long Range Plan. 2007, 40, 154-177. [CrossRef]

84. Abraham, S.C. Strategic Planning: A Practical Guide for Competitive Success; Emerald Group Publishing: Bingley, UK, 2012.

85. Carmines, E.G.; Richard, A.Z. Reliability and Validity Assessment; Sage Publications: Beverly Hills, CA, USA, 1979.

86. Chin, W.W. Issues and opinion on structural equation modeling. MIS Q. 1988, 22, vii-xvi.

87. Ahmed, P.K.; Rafiq, M. Internal Marketing-Tools and Concepts for Customer-Focused Management; Butterworth-Heinemann Publications: Oxford, UK, 2002.

88. Bansal, H.S.; Mendelson, M.B.; Sharma, B. The impact of internal marketing activities on external marketing outcomes. J. Qual. Manag. 2001, 6, 61-76. [CrossRef]

89. Ariza-Montes, J.A.; Muniz, R.N.M.; Leal-Rodríguez, A.L.; Leal-Millán, A.G. Workplace bullying among managers: A multifactorial perspective and understanding. Int. J. Environ. Res. Public Health 2014, 11, 2657-2682. [CrossRef] [PubMed]

(C) 2016 by the authors; licensee MDPI, Basel, Switzerland. This article is an open access article distributed under the terms and conditions of the Creative Commons by Attribution (CC-BY) license (http:/ / creativecommons.org/licenses/by/4.0/). 